\title{
ASUPAN KALSIUM DAN VITAMIN D PADA ANAK INDONESIA USIA 2 - 12 TAHUN
}

\author{
[Calcium and Vitamin D Intake of Indonesian Children 2-12 Years Old] \\ Victoria Valentina*, Nurheni Sri Palupi dan Nuri Andarwulan \\ Departemen IImu dan Teknologi Pangan, Fakultas Teknologi Pertanian, Institut Pertanian Bogor, Bogor
}

Diterima 18 Januari 2014 / Disetujui 25 Juni 2014

\begin{abstract}
Food consumption is playing an important role for nutritional status of children 2-12 years old. During growth and development phase, body needs macro and micro nutrients even more than later phase. The process can not be catched up at later stage therefore it is very important to pay attention to food consumption during this phase. This study used secondary data of South East Asian Nutrition Surveys (SEANUTS) 2011-2012 which was covered recapitulation profile data of 300 children age 2-12 years old representative of 48 districts in Indonesia. The study showed that Indonesian children consuming less calcium and vitamin D-rich foods than the recommended daily allowance (RDA). It does not reflects on the result of anthropometry data, vitamin $D$ on the blood and bone mass density since the dietary recall 24 hours shows only food consumption in that specific day while nutritional status shows a result of longer process. However, vitamin $D$ in blood has a significant correlation with bone mass density of tibia bone $(p<0.05)$. Deficiency of calcium and mainly vitamin $D$ is a new finding at this time. Therefore, the study showed that fortification of calcium and vitamin min D in food become important to improve nutritional status of Indonesian children. $20 \%$ of RDA per serving size twice a day is recommended as well for fortification level of Calcium and Vitamin D.
\end{abstract}

Keywords: calcium, children 2-12 years old, food intake, fortification level, vitamin D

\begin{abstract}
ABSTRAK
Konsumsi pangan mempunyai peranan penting untuk mengetahui status gizi secara umum dan terutama pada anak-anak. Selama fase pertumbuhan dan perkembangan, tubuh membutuhkan zat gizi makro dan mikro lebih besar dibandingkan pada fase dewasa Proses ini tidak bisa terkejar pada fase berikutnya, oleh karena itu sangat penting untuk memperhatikan konsumsi pangan pada fase ini. Penelitian ini menggunakan data sekunder SEANUTS 2011-2012 pada anak Indonesia 2-12 tahun meliputi jumlah sampel sebanyak 300 anak yang tersebar dari 48 Kabupaten di Indonesia, menunjukkan bahwa anak Indonesia mengonsumsi pangan sumber kalsium dan vitamin $\mathrm{D}$ yang lebih rendah dibandingkan dengan angka kecukupan zat gizi. Hal ini tidak terlihat langsung pada data antropometri, kadar vitamin D di dalam darah dan kepadatan tulang karena dietary recall 24 jam menunjukkan keadaan konsumsi pangan pada hari itu dan status gizi merupakan proses yang panjang. Namun ada korelasi yang signifikan pada kadar vitamin $\mathrm{D}$ pada darah dengan kepadatan tulang terutama tulang tibia $(p<0.05)$. Kekurangan gizi kalsium dan terutama vitamin D merupakan hal yang baru pada saat ini. Oleh karena itu fortifikasi kalsium dan vitamin $D$ pada pangan menjadi penting untuk memperbaiki status gizi anak Indonesia. Tingkat fortifikasi kalsium dan vitamin D yang dianjurkan pada pangan adalah $20 \%$ dari AKG per saji, 2 kali dalam sehari.
\end{abstract}

Kata kunci: anak umur 2-12 tahun, asupan pangan, kalsium, tingkat fortifikasi, vitamin D

\section{PENDAHULUAN}

Status gizi menggambarkan keadaan tubuh sebagai akibat konsumsi pangan dan pemanfaatan zat gizi bagi tubuh. Faktorfaktor yang dapat mempengaruhi status gizi adalah pemberian ASI, kelengkapan imunisasi, pola asuh balita, asupan makanan dan pengetahuan ibu.

Menurut Riskesdas (2010), masalah gizi di Indonesia yang terbanyak meliputi gizi kurang atau gizi tidak seimbang terutama pada kelompok anak usia 0-5 tahun. Prevalensi gizi buruk menurun menjadi $4.9 \%$ pada tahun 2010 , namun prevalensi gizi kurang masih 13\% (Trihono, 2010). Selain itu masalah gizi yang lain adalah prevalensi kekurangan zat gizi mikro seperti vitamin A, zat besi dan yodium sebesar 5.7, 12.8 dan $12.9 \%$.

*Penulis Korenspondensi:

E-mail: valenv22@gmail.com; Hp.: +65-9882879
Penelitian yang dilakukan pada umumnya menggunakan metode Dietary Recall dan Food Frequency Questionnaire namun belum dilengkapi dengan analisis secara biokimia seperti kekurangan zat gizi mikro kalsium dan vitamin D. Oleh karena itu, dalam South East Asian Nutrition Surveys (SEANUTS) 2011-2012 selain digunakan metode Dietary Recall juga dilakukan analisis biokimia. Penelitian ini dilakukan untuk mendapatkan data kecukupan gizi vitamin $D$ dan kalsium anak Indonesia. Hasil penelitian dapat digunakan untuk menyumbang data nasional yang lebih komprehensif sehingga bisa dijadikan landasan dasar dalam pengambilan kebijakan di Indonesia.

\section{BAHAN DAN METODE}

Penelitian ini menggunakan data sekunder SEANUTS 20112012 pada anak Indonesia 2-12 tahun dengan jumlah sampel 
sebanyak 300 yang tersebar di 48 kabupaten di Indonesia, dimana model yang digunakan adalah cross-sectional study dan population based study. Prosedur pengambilan sampelnya adalah multistage cluster sampling dengan metode proportionate to population size (PPS).

Data yang digunakan meliputi data konsumsi pangan berdasarkan Dietary Recall 24 jam untuk mengetahui konsumsi dan asupan pangan anak, kepadatan tulang dengan alat Quantitative Ultrasound (QUS/Omnisense 8000p, ANZHSN 2008), kandungan vitamin $D$ dalam serum darah yang dilakukan oleh tenaga terlatih dari laboratorium Prodia. Sedangkan analisis data menggunakan program SPSS.

\section{Tahapan kajian}

Data SEANUTS 2011-2012 dengan jumlah populasi 7200 sampel untuk bagian kuisioner dibagi menjadi 3 kategori umur, 2400 sampel untuk umur 6 bulan sampai dengan 2 tahun, 2400 sampel untuk umur 2 sampai dengan $<6$ tahun, 2400 sampel untuk umur 6 sampai dengan 12 tahun. Sementara itu untuk bagian non kuisioner (pengukuran kepadatan tulang dengan Omnisense 8000p, pengukuran aktivitas anak dengan Pedometer, analisa biokimia) dilakukan pengambilan sub sampel. Anak dengan umur 6 bulan sampai dengan 2 tahun tidak dilakukan pengambilan darah dari pembuluh darah vena hanya secara finger prick sehubungan dengan kode etik dari Kementerian Kesehatan.

Kriteria inklusi dari subyek adalah kondisi anak sehat tanpa ada gejala kelainan fisik, mental atau genetika dan mampu untuk berpartisipasi dalam survei tersebut. Partisipasi dari anak disetujui oleh orang tua atau kader dan ditulis dalam form inform consent. Kriteria eksklusi adalah subyek dibawah umur 6 bulan dan diatas umur 12 tahun, kondisi anak tidak sehat dengan gejala kelainan fisik, mental atau genetika. Dokter umum dari Puskesmas terdekat bertanggung jawab dalam melakukan pemeriksaan terhadap anak yang akan terlibat di dalam survei sesuai dengan kriteria inklusi dan eksklusi yang sudah disebutkan.

Analisa biokimia terutama pengukuran kadar vitamin $D$ di dalam darah dari anak umur 2 tahun keatas dilakukan dengan sub sampel sebanyak 300 terdiri dari umur $2-<6$ tahun sebanyak 150 sampel dan umur 6-12 tahun sebanyak 150 sampel. Jumlah responden antara anak laki-laki dan perempuan serta anak-anak yang tinggal di daerah pedesaan dan perkotaan adalah setara. Survei dilakukan di 48 kabupaten yang dipilih dengan acak dari 480 kabupaten di seluruh Indonesia. Tahapan kajian yang dilakukan adalah meliputi 6 tahapan yaitu: (1) rekapitulasi profil responden, (2) ekstraksi data Dietary Recall 24 jam untuk konsumsi dan asupan kalsium, (3) ekstraksi data Dietary Recall 24 jam untuk konsumsi dan asupan vitamin D, (4) rekapitulasi data kadar vitamin D di dalam darah, (5) rekapitulasi data kepadatan tulang atau Bone Mass Density (BMD), (6) analisis data.

Rekapitulasi profil responden dari anak Indonesia berusia 212 tahun yang diukur zat gizi vitamin $D$ dalam serum darah pada SEANUTS 2011-2012 meliputi nama responden, umur, jenis kelamin dan tempat tinggal. Kemudian ekstraksi data Dietary Recall 24 jam dan pengumpulan data sekunder berdasarkan pustaka untuk analisa data jumlah konsumsi pangan yang mengandung kalsium dan mengetahui asupan kalsium harian yang meliputi pengelompokan jenis pangan sumber kalsium, menghitung jumlah konsumsi pangan sumber kalsium per kapita per hari, pengumpulan data kadar kalsium pada pangan berdasarkan pustaka, menghitung asupan kalsium harian.

Setelah itu juga dilakukan ekstraksi data Dietary Recall 24 jam dan pengumpulan data sekunder berdasarkan pustaka untuk analisa data jumlah konsumsi pangan yang mengandung vitamin $D$ dan mengetahui asupan vitamin $D$ harian yang meliputi pengelompokan jenis pangan sumber vitamin $D$, menghitung jumlah konsumsi pangan sumber vitamin $D$ per kapita per hari, pengumpulan data kadar vitamin $\mathrm{D}$ pada pangan berdasarkan pustaka, menghitung asupan vitamin $D$ harian. Kemudian dilakukan rekapitulasi data kadar vitamin $D$ di dalam darah dan kepadatan tulang atau Bone Mass Density (BMD). Yang terakhir adalah analisis data statistik menggunakan software SPSS dengan melakukan uji korelasi dan uji T.

Uji korelasi yaitu salah satu teknik statistik yang digunakan untuk menganalisis hubungan antara dua variabel yang bersifat kuantitatif (Sarwono, 2012). Hubungan dua variabel yang akan dilihat pada penelitian ini adalah pengaruh asupan kalsium terhadap kepadatan tulang, pengaruh asupan kalsium dan vitamin D masing-masing terhadap kepadatan tulang dan kadar vitamin D dalam darah. Sedangkan uji T satu sampel digunakan untuk membandingkan rerata hasil pengamatan dengan suatu nilai standar tertentu (Sarwono, 2009). Pada penelitian ini akan dilihat perbandingan rerata hasil pengamatan asupan kalsium, asupan vitamin $\mathrm{D}$, kepadatan tulang dan kadar vitamin $\mathrm{D}$ di dalam darah.

\section{HASIL DAN PEMBAHASAN}

\section{Profil responden}

Total responden yang dianalisa vitamin $D$ di dalam darah adalah sebanyak 300 anak, namun setelah sampel darah diambil dan dikumpulkan ternyata 24 sampel darah mengalami lisis sehingga tidak bisa dianalisa lebih lanjut untuk mengetahui kadar vitamin $D$ di dalam darah. Total data responden yang dianalisa vitamin $D$ adalah 276 . Responden tersebut mewakili 47 kabupaten yang terletak di 24 Propinsi. Dari rekapitulasi profil responden diatas dapat dilakukan pengelompokan data berdasarkan variabel gender, umur dan tempat tinggal seperti yang dijelaskan pada Tabel 1.

Tabel 1. Pengelompokan data berdasarkan gender, umur dan tempat tinggal

\begin{tabular}{|c|c|c|c|c|c|c|c|}
\hline \multirow{3}{*}{ Umur } & \multirow{3}{*}{$\begin{array}{l}\text { Tempat } \\
\text { Tinggal }\end{array}$} & \multicolumn{6}{|c|}{ Jumlah Responden } \\
\hline & & \multicolumn{2}{|c|}{ Laki } & \multicolumn{2}{|c|}{ Perempuan } & \multicolumn{2}{|c|}{ Total } \\
\hline & & $n$ & $\%$ & $n$ & $\%$ & $\mathrm{n}$ & $\%$ \\
\hline \multirow[t]{3}{*}{$2-<6$ th } & Desa & 43 & 29.5 & 26 & 20.0 & 59 & 25.0 \\
\hline & Kota & 28 & 19.2 & 29 & 22.3 & 57 & 20.7 \\
\hline & Sub jumlah & 71 & 48.6 & 55 & 42.3 & 126 & 45.7 \\
\hline \multirow[t]{4}{*}{$6-12$ th } & Desa & 37 & 25.3 & 34 & 26.2 & 71 & 25.7 \\
\hline & Kota & 38 & 26.0 & 41 & 31.5 & 79 & 28.6 \\
\hline & Sub jumlah & 75 & 51.4 & 75 & 57.7 & 150 & 54.3 \\
\hline & Jumlah & 164 & 52.9 & 130 & 47.1 & 276 & 100.0 \\
\hline
\end{tabular}



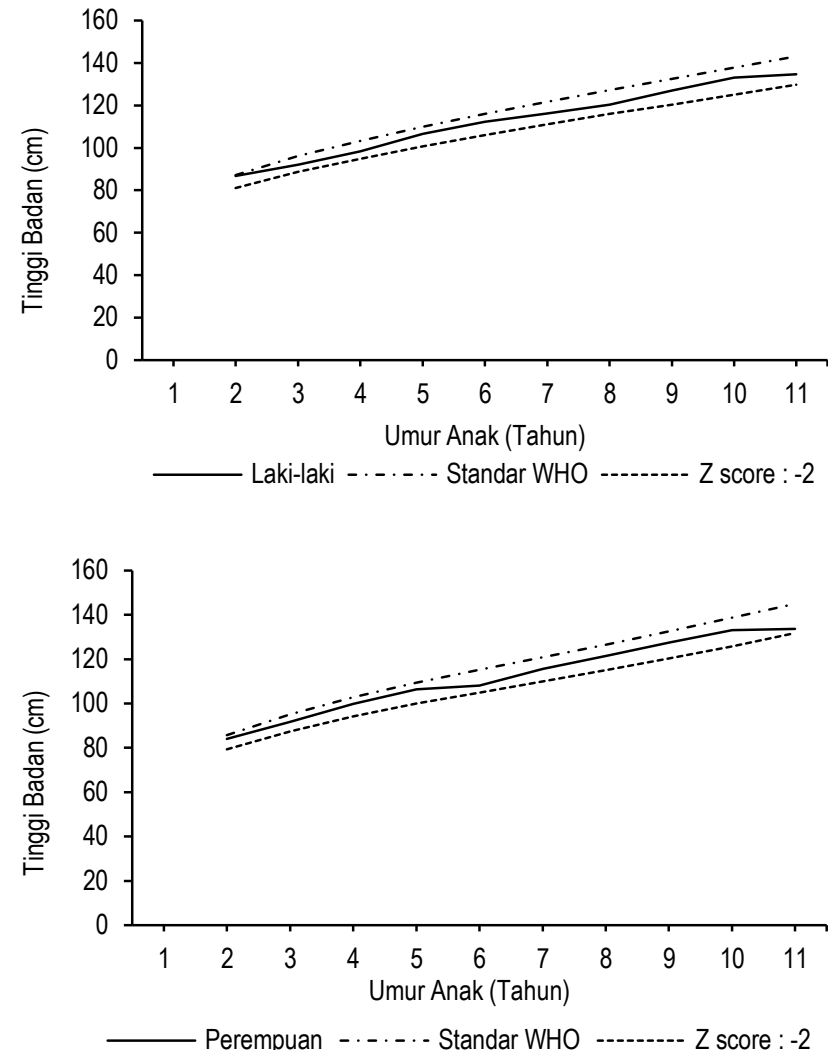

Gambar 1. Rata-rata tinggi badan anak perempuan dan laki-laki $(\mathrm{cm})$ dibandingkan dengan standar WHO
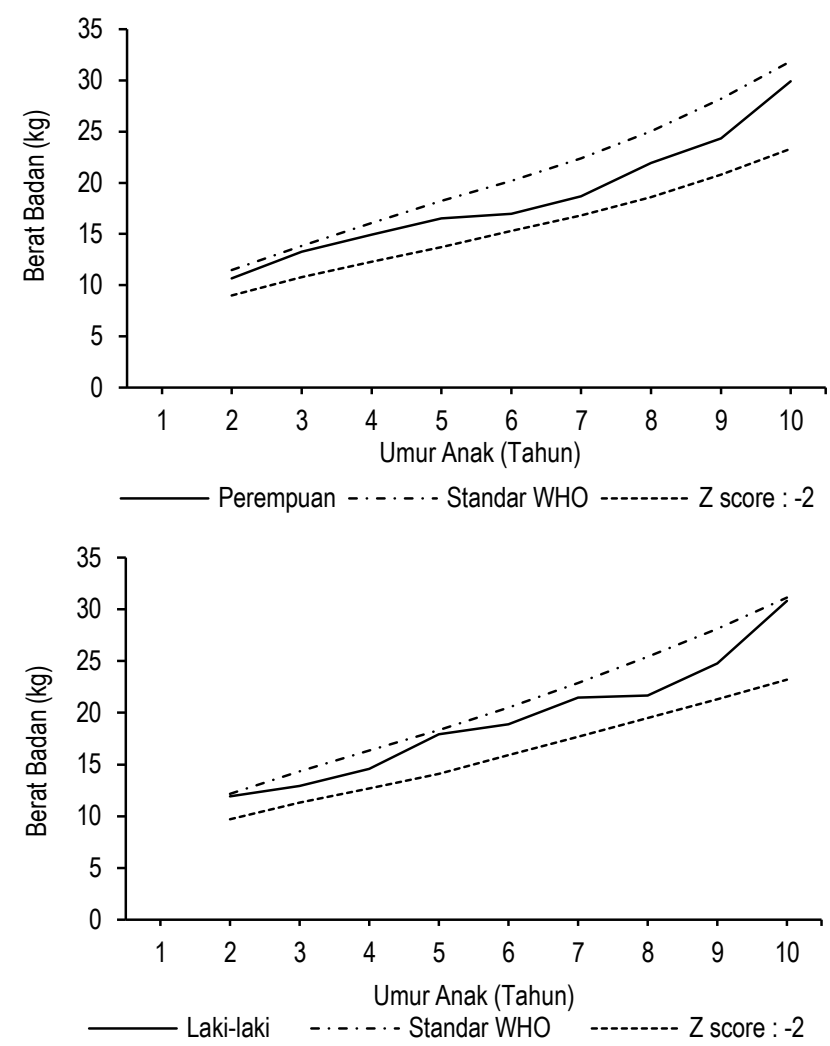

Gambar 2. Rata-rata berat badan anak perempuan dan laki-laki $(\mathrm{kg})$ dibandingkan dengan standar WHO
Gambar 1 dan 2 menjelaskan mengenai rata-rata tinggi dan berat badan hasil pengukuran antropometri dibandingkan dengan standar WHO. Jika dilihat dari data yang ada, maka tinggi badan responden berada pada kisaran normal karena masih diatas garis $Z$ skor: -2 .

Dari 276 data responden yang dikumpulkan terdiri dari $52.90 \%$ anak laki-laki dan $47.1 \%$ anak perempuan. Untuk umur yang diamati terdiri dari 2 bagian yaitu $45.70 \%$ anak-anak berusia 2-<6 tahun dan $54.30 \%$ anak-anak berusia 6-12 tahun. Sedangkan berdasarkan tempat tinggal maka $49.30 \%$ tinggal di daerah perkotaan dan $50.70 \%$ tinggal di daerah pedesaan.

Jika dilihat lebih detail dari data responden maka anak lakilaki yang berusia $2-<6$ tahun sebesar $25.70 \%$ dan yang berusia 6-12 tahun sebesar $27.20 \%$. Sedangkan anak-anak perempuan yang berusia $2-<6$ tahun sebesar $19.90 \%$ dan yang berusia $6-$ 12 tahun sebesar 27.20\%. Dari data responden ini anak laki-laki yang tinggal di perkotaan adalah sebesar $23.90 \%$ dan yang tinggal di pedesaan adalah sebesar $29 \%$. Sementara itu, anakanak perempuan yang tinggal di perkotaan adalah sebesar $25.40 \%$ dan yang tinggal di pedesaan adalah sebesar $21.70 \%$.

\section{Konsumsi dan asupan kalsium serta Vitamin D}

Dietary Recall 24 jam adalah salah satu metode kuisioner yang umum digunakan untuk mengetahui gambaran estimasi konsumsi individu dalam sehari, sehingga secara agregat dapat mengestimasi rata-rata konsumsi sehari pada tingkat penduduk di suatu wilayah. Dari ekstraksi Dietary Recall 24 jam pada sampel anak yang dianalisa kadar vitamin $D$ terdapat 231 jenis makanan (food item) yang kemudian dikelompokkan menjadi 13 golongan makanan (food category) sebagai berikut: (1) serealia dan hasil olahannya, (2) umbi berpati dan hasil olahannya, (3) kacang-kacangan dan hasil olahannya, (4) sayuran dan hasil olahannya, (5) buah dan hasil olahannya, (6) daging, unggas dan hasil olahannya, (7) ikan, kerang, udang dan hasil olahannya, (8) telur dan hasil olahannya, (9) susu dan hasil olahannya, (10) lemak dan minyak, (11) gula, sirup dan konfeksioneri, (12) bumbu-bumbu dan (13) snacks dan drinks. Untuk golongan makanan serealia dan hasil olahannya dibagi beberapa sub golongan seperti (a) beras dan produk olahannya, (b) jagung dan produk olahannya, (c) terigu dan produk olahannya dan (d) havermut dan produk olahannya. Sedangkan golongan makanan umbi berpati dan hasil olahannya dibagi beberapa sub golongan seperti (a) kentang dan produk olahannya, (b) singkong dan produk olahannya, (c) sagu dan produk olahannya dan (d) tapioka dan produk olahannya.

Golongan makanan kacang-kacangan dan hasil olahannya dibagi menjadi sub golongan seperti (a) kacang hijau dan produk olahannya, (b) kacang merah dan produk olahannya, (c) kacang tanah dan produk olahannya, (d) kelapa dan produk olahannya dan (e) kedelai dan produk olahannya.Untuk golongan sayuran dan hasil olahannya dibedakan menjadi (a) sayuran daun, (b) sayuran bunga, (c) sayuran buah, (d) sayuran akar, (e) sayuran biji dan (f) lain-lain. Golongan buah dan hasil olahannya dibedakan menjadi (a) buah dan (b) produk terolah.

Golongan makanan daging, unggas dan hasil olahannya dibedakan menjadi (a) ayam dan hasil olahannya, (b) babi dan hasil olahannya, (c) bebek dan hasil olahannya, (d) kambing dan hasil olahannya dan (e) sapi dan hasil olahannya. Untuk 
golongan ikan, kerang, udang dan hasil olahannya dibedakan menjadi (a) ikan dan hasil olahannya, (b) cumi-cumi dan hasil olahannya dan (c) udang dan hasil olahannya. Golongan telur dan hasil olahannya tidak dibagi lagi dalam sub golongan. Sedangkan susu dan hasil olahannya dibagi menjadi (a) susu pasteurisasi, (b) UHT, (c) susu bubuk, (d) susu kental manis dan (e) es krim. Golongan makanan lemak dan minyak, serta bumbu-bumbu tidak dibagi lagi dalam sub golongan. Golongan makanan gula, sirup dan konfeksioneri dibagi menjadi sub golongan (a) gula, (b) kopi, (c) konfeksioneri dan (d) sirup. Sedangkan golongan snacks dan drinks dibagi menjadi (a) snacks dan (b) minuman.

Dari ekstraksi data Dietary Recall, asupan pangan yang mengandung vitamin $D$ per kapita per harinya adalah $3.7 \mu \mathrm{g}$ sedangkan kalsium adalah $234.46 \mathrm{mg}$. Menurut IOM (2010) asupan pangan yang mengandung vitamin $D$ untuk anak usia 212 tahun adalah $600 \mathrm{IU}$ atau setara dengan $15 \mu \mathrm{g}$ per hari. Sedangkan asupan pangan yang mengandung kalsium untuk anak usia 1-3 tahun adalah $700 \mathrm{mg}$, anak 4-8 tahun adalah $1000 \mathrm{mg}$ sedangkan anak 9-13 tahun adalah $1300 \mathrm{mg}$ per hari. Hal ini menunjukkan bahwa asupan pangan yang mengandung vitamin D per kapita per harinya hanya $25 \%$ dari yang dianjurkan oleh IOM.
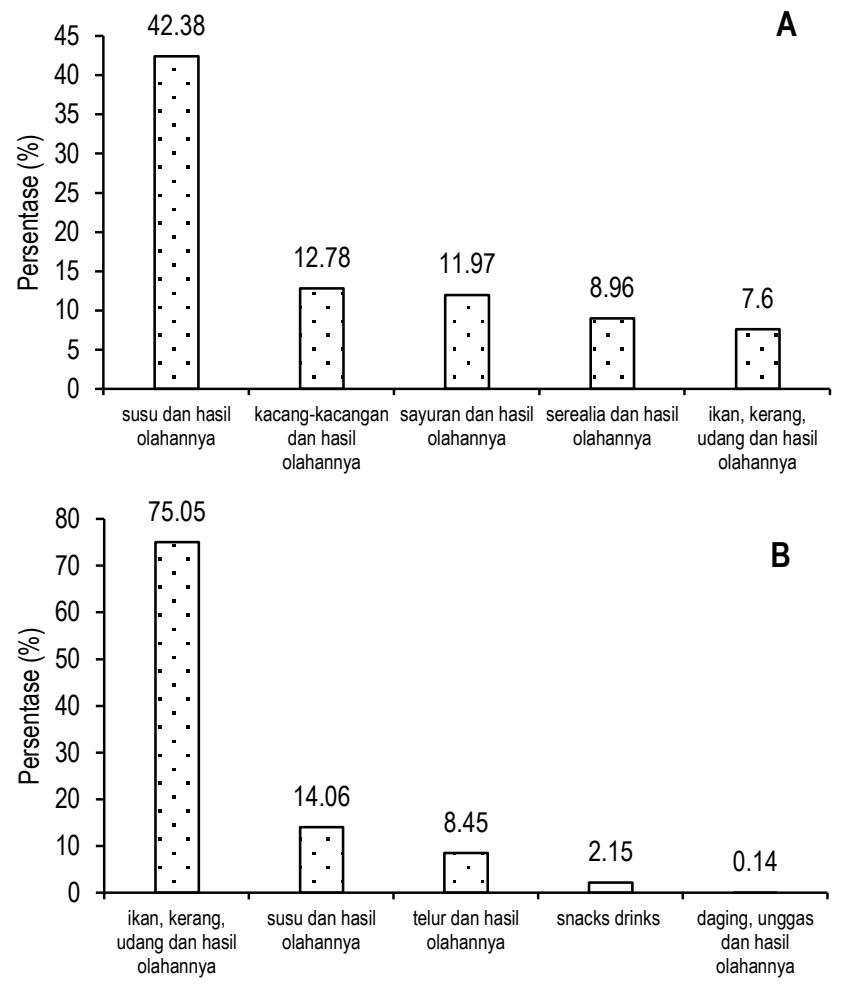

Gambar 3. Kelompok makanan yang memberikan asupan pangan terbesar untuk kalsium (A) dan vitamin $D(B)$

Berdasarkan angka kecukupan gizi (Hardinsyah, 2012) kebutuhan vitamin D untuk anak usia 2-12 tahun adalah $10 \mu \mathrm{g}$ per hari, sedangkan kecukupan kalsium untuk anak usia 1-6 tahun adalah $500 \mathrm{mg}$, sedangkan anak 7-12 tahun adalah 800 $\mathrm{mg}$ per hari. Oleh karena itu asupan yang mengandung vitamin D per kapita per harinya hanya mencapai $37 \%$ dari AKG yang dianjurkan.
Kelompok makanan yang menyumbangkan asupan kalsium paling besar adalah susu dan hasil olahannya sebesar $42.38 \%$, kacang-kacangan dan hasil olahannya sebesar $12.78 \%$, sayuran dan hasil olahannya sebesar $11.97 \%$, serealia dan hasil olahannya sebesar $8.96 \%$ serta ikan, kerang, udang dan hasil olahannya sebesar 7.6\%. Kelompok makanan yang menyumbangkan asupan vitamin $\mathrm{D}$ paling besar adalah ikan, kerang, udang dan hasil olahannya sebesar $75.05 \%$, kemudian diikuti oleh kelompok susu dan hasil olahannya sebesar $14.06 \%$, telur dan hasil olahannya sebesar $8.45 \%$, snacks dan drinks sebesar $2.15 \%$ serta daging, unggas dan hasil olahannya sebesar $0.14 \%$. Hasil ini sama dengan yang dinyatakan oleh Bowden (2008) dan PERSAGI (2009) bahwa pada umumnya pangan sumber vitamin $D$ adalah ikan dan telur. Kecukupan vitamin $D$ di dalam tubuh diharapkan mampu membantu metabolisme tulang, mengatur homeostatic kalsium plasma, meningkatkan absorpsi kalsium dan fosfat melalui usus halus (Almatsier, 2003; Yulia dan Darningsih, 2010).

\section{Kadar vitamin D di dalam darah}

Kategori yang digunakan dalam rekapitulasi data vitamin $\mathrm{D}$ di dalam darah adalah kurang dari $<30 \mathrm{nmol} / \mathrm{L}, 30-50 \mathrm{nmol} / \mathrm{L}$, $50-70 \mathrm{nmol} / \mathrm{L},>70 \mathrm{nmol} / \mathrm{L}$. Pada Gambar 4 menjelaskan hasil rekapitulasi data persentase jumlah anak dengan kadar vitamin $D$ di dalam darah.

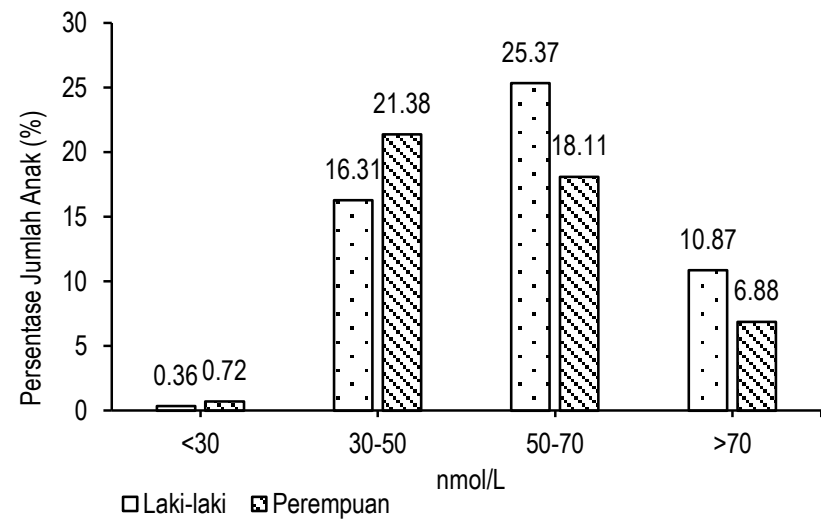

Gambar 4. Persentase jumlah anak berdasarkan kadar vitamin D di dalam darah

Jika menggunakan standar WHO (2006) dimana defisiensi kadar vitamin $\mathrm{D}$ di dalam darah adalah $<50 \mathrm{nmol} / \mathrm{L}$ maka anak laki-laki yang mengalami defisiensi vitamin $D$ adalah $16.66 \%$ sedangkan anak perempuan sebanyak $22.10 \%$ sehingga total anak laki-laki dan perempuan yang mengalami defisiensi vitamin $\mathrm{D}$ adalah $38.76 \%$. Dari data ini bisa dilihat bahwa anak perempuan mengalami defisiensi vitamin $D$ yang lebih tinggi dibandingkan anak laki-laki.

Beberapa penelitian di Amerika Serikat, Eropa, India, Australia, Amerika Selatan dan Asia Tenggara menunjukkan bahwa $50 \%$ anak dan orang dewasa mengalami resiko defisiensi vitamin $D$ yang tinggi (BCF, 2008). Hal ini juga dikatakan oleh Londhey (2011) dimana berdasarkan data yang ada pada jurnal yang sudah dipublikasi, defisiensi Vitamin D sangat umum di India pada semua kelompok umur dan jenis kelamin. Beberapa faktor yang menyebabkan defisiensi vitamin D di India adalah perubahan pola konsumsi mengandung 
asupan kalsium dan vitamin $D$ yang rendah, konsumsi serat pangan yang mengandung fosfat dan fitat dimana mengurangi penyimpanan vitamin $\mathrm{D}$ dan kalsium, faktor genetik seperti peningkatan enzim $25(\mathrm{OH}) \mathrm{D}-24$-hidroksilasi yang akan mengurangi metabolisme $25(\mathrm{OH}) \mathrm{D}$, jumlah waktu yang digunakan di dalam ruangan mengurangi paparan sinar matahari terutama orang India yang tinggal di perkotaan.

Jika dilihat dari data rata-rata kadar vitamin $\mathrm{D}$ di dalam darah responden pada Gambar 5 maka ada perbedaan yang signifikan antara laki-laki dan perempuan serta antara anakanak yang tinggal di pedesaan dan perkotaan. Hal ini sangat menarik karena kadar vitamin $D$ di dalam darah dapat dipengaruhi oleh asupan vitamin $\mathrm{D}$ sehari-hari atau kemungkinan yang lebih besar adalah pengaruh paparan sinar matahari.

Menurut WHO (2004), Setiati (2008), Soejitno dan Kuswardhani (2009) kurangnya paparan sinar matahari mempengaruhi metabolisme vitamin $\mathrm{D}$, sayangnya didalam penelitian ini tidak diukur secara detail berapa lama paparan sinar matahari yang di dapat pada anak-anak. Didalam pembahasan berikutnya akan dilihat apakah asupan pangan yang mengandung sumber vitamin $\mathrm{D}$ mempengaruhi kadar vitamin $D$ di dalam darah. Ternyata uji korelasi Pearson Chisquare menunjukkan bahwa asupan pangan vitamin $\mathrm{D}$ ( $p$-value 0.693 > alpha 5\%; OR 1.192; 95\% tingkat kepercayaan) dan kalsium ( $p$-value $0.863>$ alpha 5\%; OR 0.951; 95\% tingkat kepercayaan) tidak berkorelasi signifikan dengan kandungan vitamin D dalam darah. Menurut Holick (2007), sangat sulit untuk memenuhi kebutuhan vitamin $D$ setiap hari dari asupan pangan kecuali orang tersebut makan ikan yang mengandung tinggi lemak secara rutin. Pearce dan Cheetham (2010) menyatakan bahwa vitamin $D$ defisiensi dan insuffisien juga terjadi di Inggris dimana salah satu penyebabnya adalah kurangnya paparan sinar matahari terutama bagi mereka yang tidak melakukan aktivitas di luar ruangan. Hal yang sama dikemukakan oleh Cannell et al. (2008) bahwa konsumsi pangan secara normal mengandung sedikit sumber pangan vitamin $\mathrm{D}$ kecuali mereka yang makan ikan yang mengandung tinggi lemak. Sumber vitamin D juga bisa didapat dari makanan yang difortifikasi seperti susu, jus jeruk dan sereal, margarin. Produksi vitamin D pada kulit cukup cepat setelah beberapa menit terpapar dengan sinar matahari.

\section{Kepadatan tulang}

Kepadatan tulang akan terbaca sebagai nilai Z-skor dan nilai ini merupakan perbandingan kandungan densitas mineral tulang seseorang sesuai umur dan jenis kelamin (RCR, 2005). Menurut CAR (2010), diagnosa anak yang mempunyai Bone Mass Density (BMD) normal adalah yang mempunyai $Z$ skor value diatas -2.0; sedangkan diagnosa anak yang kurang BMDnya adalah $\leq-2.0$; oleh karena itu anak-anak yang diuji masih memiliki kepadatan tulang yang normal karena Z skor > 2.0. Uji korelasi Pearson Chi-square menunjukkan bahwa asupan pangan kalsium dan vitamin $\mathrm{D}$ tidak berkorelasi signifikan dengan kepadatan tulang ( $p$-value $0.745>$ alpha $5 \%$; OR 1.231; $95 \%$ tingkat kepercayaan untuk asupan pangan kalsium dan p-value $0.380>$ alpha 5\%; OR 0.505; $95 \%$ tingkat kepercayaan untuk asupan pangan vitamin D). Namun dari hasil uji korelasi, terlihat hubungan yang signifikan antara vitamin $D$ di dalam darah dan kepadatan tulang, karena memiliki $p$-value kurang dari 0.05 .

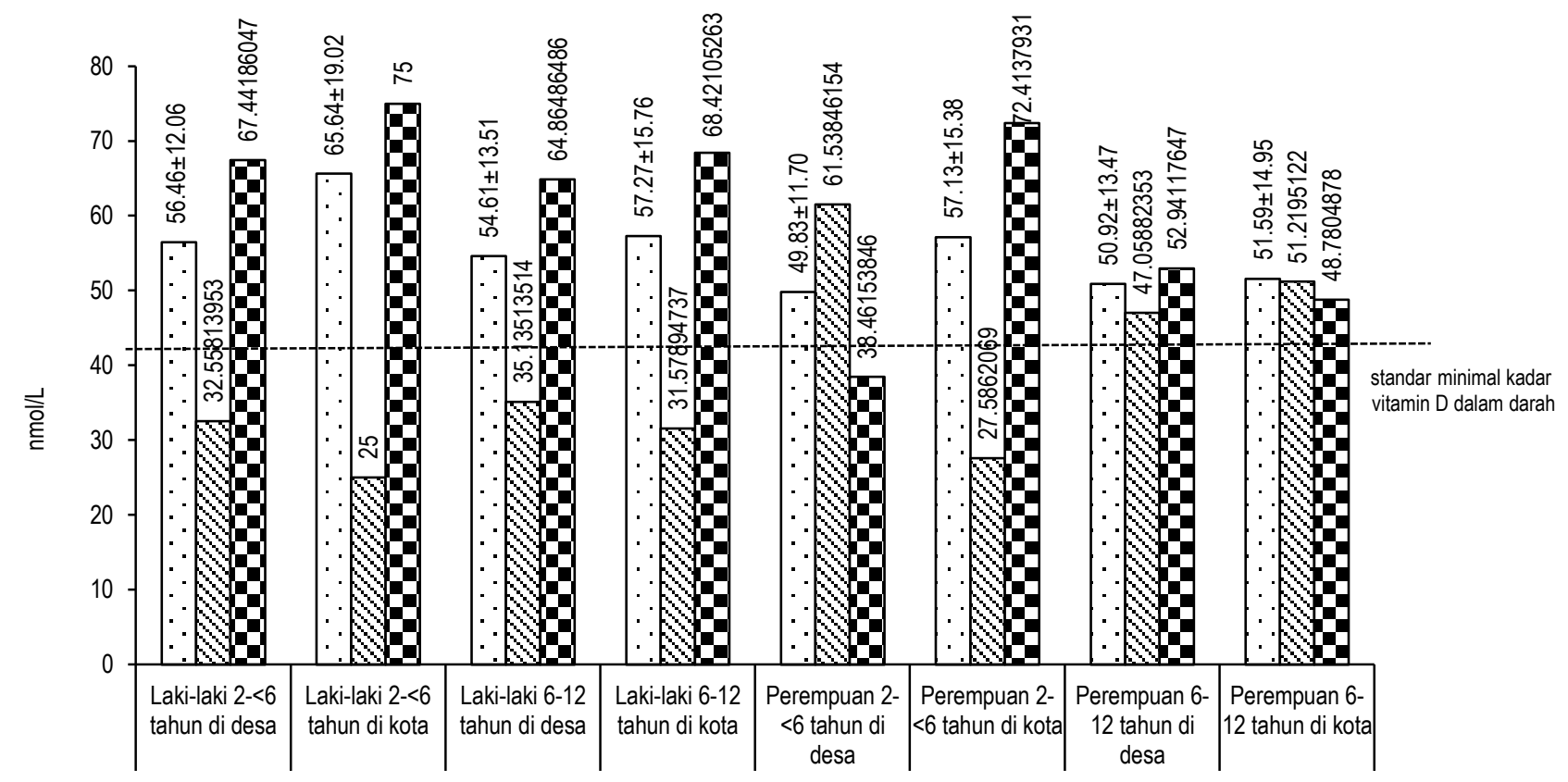

$$
\begin{array}{rrr}
\square \text { rata-rata kadar vit } D & \square \% \text { anak dengan } & \square \% \text { anak dengan } \\
\text { dalam darah anak (nmol/L) } & \text { vit } D<50 \mathrm{nmol} / \mathrm{L} & \text { vit } \mathrm{D}>50 \mathrm{nmol} / \mathrm{L}
\end{array}
$$




\section{Fortifikasi kalsium dan vitamin $D$}

Fortifikasi pangan mengacu kepada penambahan satu atau lebih zat gizi pada bahan pangan tersebut baik untuk menambahkan zat gizi yang belum ada atau memperkaya zat gizi yang sudah ada. Hal ini dilakukan untuk meningkatkan kesehatan masyarakat dalam menanggulangi status defisiensi zat gizi yang ada ataupun meningkatkan nilai gizi dari suatu produk. Fortifikasi kalsium biasanya dilakukan pada kategori produk seperti susu formula, susu pertumbuhan, sereal (Holick dan Chen, 2008) dan minuman lainnya seperti susu kedelai. Jenis kalsium yang sering ditambahkan adalah kalsium susu, kalsium karbonat, kalsium fosfat dan kalsium laktat (Hurrell, 1999).

Fortifikasi vitamin D biasanya dilakukan pada kategori produk seperti susu dan sereal, mentega, margarin (Calvo et al. 2004) karena vitamin D merupakan vitamin yang larut lemak. Jenis vitamin $\mathrm{D}$ yang sering ditambahkan adalah vitamin $\mathrm{D} 2$ dan vitamin D3 dengan jumlah sedikitnya 20-25 $\mathrm{\mu g} /$ hari (Holick dan Chen, 2008). Di Amerika dan Kanada dilakukan standarisasi fortifikasi susu dengan kalsium dan vitamin D. Penambahan vitamin $\mathrm{D}$ yang diatur secara hukum di Amerika dibagi menjadi dua yaitu wajib seperti susu bubuk, susu evaporasi $(10 \mu \mathrm{g} / 946$ $\mathrm{mL})$ dan sukarela seperti yogurt, margarin, jus $(2.5 \mu \mathrm{g} / \mathrm{saji})$ Fortifikasi vitamin D di Kanada pada susu sebesar $44 \%$ dari RDA $(10 \mu \mathrm{g})$ yaitu $4.4 \mu \mathrm{g}$ per saji $(250 \mathrm{~mL})$. Semua margarin di Kanada difortifikasi dengan vitamin D sebesar $13.25 \mu \mathrm{g} / 100 \mathrm{~g}$. Untuk membantu orang yang tidak terbiasa minum susu maka dilakukan fortifikasi kalsium dan vitamin $D$ pada jus jeruk (Calvo et al. 2004). Fortifikasi kalsium dilakukan pada kategori produk seperti susu, sereal, susu kedelai dan jus. Fortifikasi kalsium pada roti, sereal sebesar $55 \mathrm{mg} / \mathrm{saji}$ ( $5 \% \mathrm{RDA})$, pasta sejumlah $130 \mathrm{mg} / \mathrm{saji}$ (13\% RDA) dan jus sebesar $300 \mathrm{mg} / \mathrm{saji}$ (30\% RDA) (Johnson-Down et al. 2003).

Asupan pangan kalsium dan vitamin $D$ pada penelitian ini adalah $234.46 \mathrm{mg}$ dan $3.70 \mu \mathrm{g}$. Kombinasi tersebut menunjukkan tidak adanya korelasi yang positif dengan kepadatan tulang. Hal ini dapat disebabkan oleh beberapa faktor seperti adanya factor penganggu penyerapan kalsium dan vitamin $D$ di dalam tubuh, kurangnya paparan sinar matahari dan kurangnya aktifitas fisik. Meskipun demikian, namun menurut Arifin et al. (2010) susu yang difortifikasi kalsium tinggi (1200 mg/hari) dan vitamin $D(9.6 \mu \mathrm{g} /$ hari) terbukti dapat memperbaiki status vitamin $\mathrm{D}$, mengurangi kadar parathyroid hormone (PTH) dan menurunkan turnover tulang secara bermakna. Pemberian susu yang difortifikasi kalsium tinggi dan vitamin $D$ lebih baik dibandingkan dengan pemberian susu kalsium rendah dalam menurunkan bone turnover meskipun penelitian dilakukan pada perempuan pascamenopause bukan pada anak.

Oleh karena itu anjuran untuk fortifikasi kalsium dan vitamin D pada produk pangan seperti susu sebaiknya memenuhi klaim "mengandung" (20\% dari AKG) berarti untuk kalsium sebesar $160 \mathrm{mg}$ dan vitamin D $2 \mu \mathrm{g}$ per saji. Rekomendasi yang lain adalah mengonsumsi produk pangan yang sudah difortifikasi tersebut paling tidak 2 kali dalam sehari.

\section{KESIMPULAN}

Jenis pangan yang dikonsumsi sebagai sumber asupan kalsium adalah susu dan olahannya; kacang-kacangan dan hasil olahannya serta sayuran dan hasil olahannya. Jenis pangan yang dikonsumsi sebagai sumber asupan vitamin $D$ adalah ikan, kerang, udang dan hasil olahannya, susu dan hasil olahannya; serta telur dan hasil olahannya. Pada penelitian ini konsumsi pangan dalam bentuk susu dan olahannya sebanyak $34.11 \mathrm{~g} / \mathrm{kapita} / \mathrm{hari}$, sedangkan dalam bentuk produk ikan, kerang, udang dan hasil olahannya sebanyak 33.47 $\mathrm{g} / \mathrm{kapita} /$ hari. Asupan pangan untuk kalsium adalah $234.46 \mathrm{mg}$ dan vitamin D adalah $3.70 \mu \mathrm{g}$.

Rata-rata persentase AKG per hari untuk energi dengan cut off point yang ditentukan ternyata mencapai $84 \%$ pada usia 2-3 tahun, namun semakin bertambahnya usia maka semakin rendah energi yang tercukupi (45\% pada usia 10-12 tahun). Rata-rata kecukupan gizi protein untuk anak 4-6 tahun sebesar $88 \%$, namun sayangnya seiring dengan bertambahnya umur, asupan proteinnya berkurang. Hal ini juga terlihat pada kecukupan gizi yang lain seperti lemak, karbohidrat, kalsium dan vitamin $\mathrm{D}$.

Dengan menggunakan standar WHO defisiensi kadar vitamin $D$ di dalam darah adalah $<50 \mathrm{nmol} / \mathrm{L}$ maka anak lakilaki yang mengalami defisiensi vitamin $D$ adalah $16.66 \%$ sedangkan anak perempuan sebanyak $22.10 \%$, total anak lakilaki dan perempuan yang mengalami defisiensi vitamin $D$ adalah $38.76 \%$. Dari data ini bisa dilihat bahwa anak perempuan mengalami defisiensi vitamin $D$ yang lebih tinggi dibandingkan anak laki-laki. Responden (anak-anak) yang diuji memiliki kepadatan tulang yang normal karena mempunyai Bone Mass Density (BMD)dengan Z skor diatas -2.0.

Pada penelitian ini, asupan pangan vitamin $D$ dan kalsium tidak berpengaruh secara signifikan terhadap status gizi seperti kadar vitamin $D$ dalam darah dan kepadatan tulang. Fakta lain yang didapat dari penelitian ini adalah terdapat hubungan yang signifikan antara vitamin $D$ di dalam darah dan kepadatan tulang, karena memiliki $p$-value kurang dari 0.05 . Sehubungan dengan adanya faktor penghambat dalam penyerapan zat gizi di dalam tubuh, maka fortifikasi zat gizi masih penting untuk dilakukan. Oleh karena itu fortifikasi kalsium dan vitamin D direkomendasikan dapat dilakukan pada beberapa produk pangan seperti susu, sereal dan margarin untuk memperbaiki status gizi anak Indonesia. Fortifikasi yang disarankan adalah minimum $20 \%$ dari AKG per saji (kalsium $160 \mathrm{mg}$ dan vitamin D $2 \mu \mathrm{g})$ dan mengonsumsi produk yang sudah difortifikasi setidaknya 2 kali sehari.

\section{UCAPAN TERIMA KASIH}

Penulis mengucapkan terima kasih kepada Friesland Campina atas pemberian ijin untuk menggunakan data SEANUTS, kepada tim SEANUTS (Dr. Anne Schaafsma, Dr. Panam Parikh, Dr. Ilse Tan Khouw, Dr. Basuki Budiman, Dr. Moesijanti Soekatri, dan Dr. Yudarini Harahap) atas masukan dan saran yang diberikan, khususnya kepada Dr. Sandjaja, $\mathrm{MPH}$. 


\section{DAFTAR PUSTAKA}

Almatsier S. 2003. Prinsip Dasar IImu Gizi. 132-150. Gramedia, Jakarta.

[ANZHSN] Australia and New Zealand Horizon Scanning Network. 2008. Quantitative ultrasound (QUS). Australia.

Arifin Z, Hestiantoro A, Baziad A. 2010. Pemberian susu yang difortifikasi kalsium kadar tinggi dan vitamin $D$ dalam memperbaiki turnover tulang perempuan pascamenopause. Majalah Obstetri dan Ginekologi Indonesia 34: 31-38.

[BCF] The Bone and Cancer Foundation. 2008. Vitamin D Deficiency: Information for Cancer Patients. America.

Bowden SA, Robinson RF, Carr R, Mahan JD. 2008. Prevalence of vitamin $D$ deficiency and insufficiency in children with osteopenia or osteoporosis referred to a pediatric metabolic bone clinic. Pediatrics 121: e1585-e1590. DOI: 10.1542/ peds.2007-2111.

Cannell JJ, Hollis BW, Zasloff M, Heaney RP. 2008. Diagnosis and Treatment of Vitamin D Deficiency. America.

Calvo MS, Whiting SJ, Barton CN. 2004. Vitamin D fortification in the Unites States and Canada : current status and data needs. Am J Clin Nutr 80: 1710S-1716S.

[CAR] Canadian Association of Radiologists. 2010. CAR Technical Standards for Bone Mineral Densitometry Reporting. Canada.

Hardinsyah, Riyadi H, Napitupulu V. 2012. Kecukupan Energi, Protein, Lemak dan Karbohidrat. Bogor, Indonesia.

Holick MF. 2007. Vitamin D deficiency. New Eng J Med 357: 266-281. DOI: 10.1056/NEJMra070553.

Holick MF, Chen TC. 2008. Vitamin D Deficiency : a worldwide problem with health consequences. Am J Clin Nutr 87: 1080S-1086S.

Hurrell R. 1999. The Mineral Fortification of Foods. England.

[IOM] Institute of Medicine. 2010. Dietary Reference Intakes for Calcium and Vitamin D. America.
Londhey V. 2011. Vitamin D deficiency: indian scenario. J Assoc Physicians India 59: 695-696.

[PERSAGI] Persatuan Ahli Gizi Indonesia. 2009a. Kamus Gizi Pelengkap Kesehatan Keluarga. 259-260. Kompas, Jakarta.

Pearce S, Cheetham T. 2010. Diagnosis and management of Vitamin D deficiency. Brit Med J 340: b5664. 142-147. DOI: 10.1136/bmj.b5664.

[RCR] Royal College of Radiologists. 2005. Standards for Ultrasound Equipment. Inggris.

Sarwono J. 2009. Statistik itu mudah: Panduan Lengkap Untuk Belajar Komputasi Statistik Menggunakan SPSS 16. Penerbit Andi, Yogyakarta.

Sarwono J. 2012. Metode Riset Skripsi Pendekatan Kuantitatif: Menggunakan Prosedur SPSS. Elex Media Komputindo, Jakarta.

Setiati S. 2008. Pengaruh sinar ultraviolet B matahari terhadap konsentrasi vitamin $\mathrm{D}$ dan hormon paratiroid pada perempuan usia lanjut Indonesia. J Kesehatan Masyarakat Nasional 2: 147-153.

Soejitno A, Kuswardhani RAT. 2009. Defisiensi vitamin D: mekanisme, implikasi dan terapi pada lansia. Cermin Dunia Kedokteran 36: 81-83.

Trihono. 2010. Riset Kesehatan Dasar. Badan Penelitian dan Pengembangan Kesehatan. Kementerian Kesehatan RI, Jakarta.

[WHO] World Health Organization. 2004. Vitamin and Mineral Requirements in Human Nutrition. Bangkok.

[WHO] World Health Organization. 2006. WHO Child Growth Standards. France.

Yulia C, Darningsih S. 2010. Hubungan Kalsium dengan Ricketsia, Osteomalacia dan Osteoarthritis. Jakarta. Fakultas Kedokteran, Universitas Pembangunan Nasional Veteran. 